UDC 811.111'373

DOI https://doi.org/10.32837/2312-3192-2018-11-21-28

\title{
CONCEPTUAL ANALYSIS OF THE PSYCHOLOGICAL PORTRAIT OF BILLY MILLIGAN'S MULTIPLE PERSONALITY EVOLUTION
}

\begin{abstract}
Alla Golovnia ${ }^{1}$
Abstract

The article sets out to provide the results of the conceptual investigation of the notion of the multiple personality portrait and the process of the conceptual sphere formation on its subconscious, mental and psychological levels being based on the investigation of the linguistic means of expressing the characteristics of the protagonist and his alter-egos by means of the English language. The relevance of the work is caused by the considerable attention currently paid to the ways of human cognitive activity verbal representation in English-language fine literature along with peculiarities of its translation into modern the Ukrainian language, because this aspect is still questionable and remains to be one of the most difficult tasks in the translator's work from English to Ukrainian in particular. Linguistic and conceptual features of the multiple personality representation in the fine literature were thoroughly examined in the novel "The Minds of Billy Milligan" by Daniel Keyes whose works were awarded with two of the most prestigious prizes in the spheres of English scientific prose. The research showed that psychological portrait of Billy Milligan`s (the protagonist of the novel) multiple personality can be studied only as a complex image because it involved 23 completely different alter-ego with split conceptual sphere in each of it. Every new personality had their own name, look, age, character, manner of speech, behavior, IQ level and also particular role to play in Milligan`s body. Depending on their function, stage of development and core personality`s self-improvement level, every new concept was represented in the English language with the help of different linguistic and stylistic means. While making investigations it was determined that the process of verbal representation and further translation of the multiple personality's conceptual sphere is extremely difficult, because it requires not only constant and in-depth study of linguistic units, but also thorough analysis on the psychological and subconscious levels.
\end{abstract}

Keywords

Fine Literature, Multiple Personality, Psychological Portrait, Concept, Conceptual Sphere, Verbalization, Linguistic and Stylistic Means, Translation Techniques

1. Introduction. The issue of concept dependence on verbal representation, connection between concept and meaning, availability of evaluative, emotive, axiological and pragmatic components in the concept structure $^{2}$, as well as concept appliance to individual or collective awareness are among the most debating issues of modern conceptual linguistics ${ }^{3}$. The scientists lay stress on stylistic means and expressive devices that present some concepts or notions thus investigating a deeper representation of the plot or artistic image ${ }^{4}$. Thereby a character portrait is one of the key means of the image creating ${ }^{5}$, and can be treated as a part of problem that promotes investigating translation ${ }^{6}$ and communication in general.

\footnotetext{
${ }^{1}$ Assoc. Prof., Doc. A. V. Golovnia, National Aviation

University, 1, Kosmonavta Komarova Ave., 03058, Kyiv, Ukraine, Email: allagolovnia2017@gmail.com.

ORCID ID: 0000-0002-0478-264X

${ }^{2}$ Krasnykh, 1997; Nayer, 2002

${ }^{3}$ Van Dijk, 1997

${ }^{4}$ Risager, 2006; Gannon, 2003

${ }^{5}$ Voronova, 2010

${ }^{6}$ Robinson, 2002; Snell-Hornby, 2006; Munday, 2008

${ }^{7}$ Voronova, 2010, 44-45

${ }^{8}$ Kusko, 1980, 134-142, 167-170

${ }^{9}$ Goncharova, 1984, 54-68

${ }^{10}$ Belekhova, 2012, 31-32; Belekhova, 2013, 53-54

${ }^{11}$ Keyes, 2013
}

The purpose of the work is to study the means of contributing to the conceptualization and linguistic representation of the portrait of multiple personality in fiction and the peculiarities of its rendering in translation. The object of the research is means of conceptualization of the portrait of the multiple personality. The subject of the research is linguistic means of the portrait of the multiple personality conceptualization.

2. Methodology. A great interest in the phenomenon of a portrait as a genre of artistic discourse, its typology and functions, alongside with investigation of the ways of the artistic portrait rendering have become the subject of a number of linguistic researches such as M. Voronova ${ }^{7}$, K. Kusko ${ }^{8}$ etc. A number of researchers such as Ye. Goncharova ${ }^{9}$, L. Belekhova ${ }^{10}$ etc. investigate structural, compositional, linguistic and cognitive aspects of the portrait. Besides, the advance analysis of the phenomenon mentioned enhanced the appearance of a number of portrait definitions as "portrait of a hero of a literary work".

Considering the urgent issues of translation studies, Daniel Keyes's novel "The Minds of Billy Milligan"11 was chosen for a thorough linguistic and conceptual analysis of the evolution of a portrait of a multiple personality in view of the genre and linguistic style, as well as other peculiarities of the representation of the protagonist of the work in the language of the original and in translation. Within the conducted research over 450 language units that are used to create the image of the multiple personality in the novel have been analyzed. 
3. Results and Discussion. Daniel Keyes is an extremely interesting author for translation studies, since he became the only fantasy writer who managed to get two of the most prestigious awards in English science fiction for his works. However, selecting the topic for one of his novels, the writer realized that life is often more surprising than any fiction, because the story of Billy Milligan described by the writer was real and took place in the mid-1970s in the United States, Ohio.

The original title of the work of Daniel Keyes sounds like: "The Minds of Billy Milligan", which literally should be interpreted as "the multiple minds of Billy Milligan", where in the title of the work directly the author of a novel states that the mind of the protagonist overshadows the multiple personality, however, in Ukrainian, the translator, Olena Stusenko, recreated the name by analogy with the Russian-language translation of the novel, namely "The Mysterious History of Billy Milligan", using this method of generalization.

It should be noted that such a means in the context of the novel title translation is fully justified since the story of a young man is really mysterious, namely: Billy Milligan, a twenty-year-old boy, arrested as a rapist and robber, however, it turns out that the defendant does not understand what $\mathrm{He}$ is accused of arguing that everything else has been done by someone else:

"... When she left Billy, Judy Stevenson found herself in turmoil, awed, angry, confused. It was all incredible. Impossible. But somewhere in the back of her mind, she knew, she was beginning to believe in his story about split personality ...".

While the investigators believe that Milligan is playing tricks, the doctors understand that the boy is not really all right with self-identification. Psychiatrists begin to communicate with Billy and find that his consciousness is split into 24 individuals, of whom there are desirable and undesirable, good and bad, children and adults.

Of all the multiple personalities, there were 10 leading and desirable ones:

1. Billy Milligan is the only person who really exists in the world; he is described as follows:

“... William Stanley Milligan ("Billy”), 26. The original, or core, personality, later referred to as "the unfused Billy," or "Billy-U." High school dropout. Six feet tall, 190 pounds. Blue eyes, brown hair ...".

2. Allen is a bold alter-ego of Billy Milligan who first comes into contact with the investigators; the author characterizes him as follows:

"... Allen, 18. The con man. A manipulator, he is the one who most often deals with outsiders. He is an agnostic, and his attitude is, "Make the best of life on earth." He plays the drums, paints portraits and is the only one of the personalities who smokes cigarettes. Has a close relationship with Billy's mother.
Same height as William, though he weighs less (165). Hair parted on right, he is the only one who is right-handed ... ".

3. David is a child in the body of Billy, a person who does not appear before the investigators, but only to the doctors, because of his empathy and infantilism requires a special psychological approach, the author has depicted him as follows:

“... David, 8. The keeper of pain, or the empath. Absorbs all the hurt and suffering of the other personalities. Highly sensitive and perceptive, but has a short attention span. Confused most of the time. Dark reddish-brown hair, blue eyes, physically small ...".

4. Christine is a little girl waking up in the body of Billy at times of punishment and special shame:

"... Christine, 3. The comer child, so called because she was the one to stand in the comer in school. A bright little English girl, she can read and print, but has dyslexia. Likes to draw and color pictures of flowers and butterflies. Blond shoulder-length hair, blue eyes ...".

5. Christopher embodies an obedient and merry ego-state, who is the boy in the body of Billy, and according to the legend is an elder brother Christine, entertains her at the moments of sadness:

“... Christopher, 13. Christenes brother. Speaks with a British accent. Obedient but troubled. Plays the harmonica. Hair brownish-blond like Christine's, but his bangs are shorter ...".

6. Arthur is a dominant alternative-personality, all others are subordinated to him, Daniel Keyes describes him as follows:

“... Arthur, 22. The Englishman. Rational, emotionless, he speaks with a British accent. Self-taught in physics and chemistry, he studies medical books. Reads and writes fluent Arabic. Though he is staunchly conservative and considers himself a capitalist, he is an avowed atheist. The first to discover the existence of all the others, he dominates in safe places, deciding who in the "family" will come out and hold he consciousness. Wears glasses ...".

7. Tommy is a unique personality, as he emerges and releases Billy from the camisole, bewildering the doctors since no ordinary person is capable of it, the following explanation becomes:

"... Tommy, 16. The escape artist. Often mistaken for Allen, he is generally belligerent and antisocial. Plays the saxophone and is an electronics specialist and a painter of landscapes. Muddy-blond hair and amber-brown eyes ...".

8. Ragen Vadascovinich is an individual with a superhuman power and aggression who wakes up at times of danger or during a conflagration with hostile investigators, has many features in both character and behaviour, and in appearance:

“... Ragen Vadascovinich, 23. The keeper of hate. His name is derived from "rage-again." Yugoslavian, 
he speaks English with a noticeable Slavic accent, and reads, writes and speaks Serbo-Croatian. A weapons and munitions authority as well as a karate expert, he displays extraordinary strength, stemming from the ability to control his adrenaline flow. He is a communist and atheist. His charge is to be the protector of the family, and of women and children in general. He dominates the consciousness in dangerous places. Has associated with criminals and drug addicts, and admits to criminal, sometimes violent behavior. Weighs 210 pounds, has enormous arms, black hair and a long, drooping mustache. He sketches in black and white because he is color-blind ... ".

9. Danny is a frightened teenager, appears when Billy is touched by men; disclosed only in the presence of a psychologist, or while drawing, in the novel described as:

"... Danny, 14. The frightened one. Afraid of people, especially men. He was forced to dig his own grave and was then buried alive. Thus he paints only still lifes. Shoulder-length blond hair, blue eyes, short and slender ...".

10. Adalana appeared during the interrogation in order to confess to rape and remove Billy and Ragen's suspicions, described by the author as:

"... Adalana, 19. The lesbian. Shy, lonely and introverted, she writes poetry, cooks and keeps house for the others. Adalana has long, stringy black hair, and since her brown eyes occasionally drift from side to side with nystagmus, she is said to have "dancing eyes ...".

Moreover, apart from the leading desirable personalities, there were those who, for disobedience, violation of rules or asocial behavior, became undesirable, so Arthur did not allow them to control the consciousness of Milligan, but nevertheless they had some influence on character in the core personality, and their presence was diagnosed directly by doctors:

Philip: Arthur punished him and allocated him to the undesirable because of the senselessness of the crimes that he committed for entertainment.

Kevin was a partner and planned the foolish theft of Philip, for these reasons Arthur also banned his appearance.

Walter: his thirst for adventures and hunting brought everyone into troubles, which is why Arthur thought it necessary to use Walter's ability to know the way round only under extraordinary circumstances, keeping him the remaining time unwanted.

April appear in the beginning as a female alter-ego to Billy, she cared about everybody and the dwelling, but subsequently went mad for a rape, became dangerous and aggressive, which forced Arthur make her undesirable.

Samuel is a person who, under any circumstances and with the slightest difficulty, lost control of himself, despaired, knelt and began to pray; Arthur did not understand this and for security reasons he made him sleep
Mark is one of those who did anything without asking even a single question, but his lack of initiative and dedication frightened Arthur, so he thought it dangerous to trust him Billy's full consciousness, so he used Mark only sometimes as a "workhorse":

Steve is the only personality that denies the existence of other alter-ego. He constantly mocks at others stepping at their toes; Arthur regards it as very dangerous, therefore, he does not allow for the management of consciousness to him.

Lee is a very frivolous person that has the ability to parody, however, imitating Steve's behavior became unbearable, endangers others by his jokes.

Jason is a hysterical personality; Arthur allows him to control consciousness only in the cases where it is necessary to get rid of excess accumulated negative emotions and only for a short period of time.

Robert (Bobby): Arthur does not allow him to manage consciousness, because he is not ambitious, lazybones and a dreamer.

Sean is undesirable because of mental retardation, cannot say and hear anything.

Martin: because of his pride, thirst for profit and ostentatious praise has become undesirable for the conservative Arthur.

Timothy (Timmie): after sexual harassment he is locked in itself and no longer wants to go out to control the consciousness; he is undesirable by his own will.

The so-called Teacher who at the time of the conversation turned 26 years old, like Billy, is a generalizing, $24^{\text {th }}$ personality:

"... The Teacher, 26. The sum of all twenty-three alter egos fused into one. Taught the others everything they've learned. Brilliant, sensitive, with a fine sense of humor. He says, "I am Billy all in one piece," and refers to the others as "the androids I made ... ".

It follows that each of the individuals has its own name and plays a certain "role" on the "stage", being responsible either for the logic of action, for protection, empathy, comfort, love, self-improvement or decline, for tenderness or aggression in the behaviour of the core personality from birth - Billy Milligan.

From the example above, it is clear that all individuals live according to the rules established by Arthur, and only the core personality does not want to be himself, does not want to enter the "scene", which would mean stepping on a spot of light in his own mind and accounting for the crime committed in the real world.

Daniel Keyes in his novel described the real story heard directly from Billy Milligan and based on the eyewitness testimony. However, in the artistic discourse to adequately reflect the situation associated with the intricate psychological state of the protagonist of the work, given the phenomenon of splitting his personality, the mere description of the disease from the diagnosis of doctors or medical aid would not be enough. That is why, for the full revelation of 
the image of each of 23 individuals in the body of Billy Milligan, the author used a number of linguistic-style techniques and conceptual priorities, which subsequently formed a holistic psychological portrait of the protagonist of the novel.

From the descriptions of each personality and their destination in the fate of Billy Milligan, the fact that they all differed not only in features, abilities and characters, but also in appearance, age, behavior, and eventually level of IQ is evident. Therefore, for the realization of the author's artistic conception, based on a full-fledged linguistic representation of the complex image of a multiple personality and the verbalization of the psychological portrait of the hero of the work, Daniel Keyes relied not only on his characteristic linguistic tools, he also paid a particular attention to the modeling of the conceptual sphere of each individual. Thus, the author revealed the links between the cognitive mechanisms of the conscious and the unconscious, moving from the thought in the head of each of the individuals to the word that this or that individual of Billy as a separate living person, could react to different situations, expressing at the same time his own impressions, observation and experience. In view of this, during the study of the specific features and changes that Billy Milligan underwent in the novel, in the first place it was necessary to perform the conceptual analysis of the evolution of the portrait of his multiple personality.

Based on the polar model of the concept structure essence according to I. Sternin ${ }^{12}$, as well as on the research theories of conceptual analysis by M. Alifirenko ${ }^{13}$, considered as the basis of our research, we found 3 basic and 3 derivative phases of the evolution of the plural identity of the protagonist of the novel: 1. The phase of regression and degradation: Full disorder among individuals; 2 . The phase of rebirth and gradual development: the unity of "desirable" individuals during therapy; 3 . The phase of progress and recovery: From "common consciousness" to a gradual merger.

The step-by-step plan highlights the fact that at the beginning of the novel, Daniel Keyes describes the really terrible situations of violations of the law, rape, threats, robberies and the arrest of Billy Milligan on suspicion, and subsequently accusation of all these crimes. Thus, during the first phase, based on the author's bright descriptions of Billy's substantive and practical criminal activity, the concept-image of a true shameless gentry appears in the imagination, which is associated with the thinking correlators of the worst representatives of this category, that is, those villains who are the part of mafia and other terrorist groups:

\footnotetext{
${ }^{12}$ Sternin, 201, 60-6213

${ }^{13}$ Alifirenko, 2010, 124-136, 145-153
}

"If you go to the police, don't give them my description. If I see anything in the newspapers, I won't come myself, but "brotherhood" will take care of your family and you." Then he took the names of relatives so to prove his threats. Later she, and the police assumed in such way this scoundrel was boasting about being part of a terrorist organization or the Mafia ...".

That is why moral decay that at the peripheral level of individual perception can be associated with such negative features as: imbalance, aggressiveness and cruelty can be considered as the core of Billy Milligan's personality concept in the first phase of regression and degradation. It is due to the complete disorder among the individuals in the body of the boy. At this stage Billy Milligan's body is subdued and used as a "puppet" in his hands, or rather, in the minds of the strongest alter-ego, so this level of the conceptual sphere is verbalized by the author by 4 people out of 23, namely: by Arthur, Ragen, Tommy and Adalana. So, moving from the thought to the word of each of these individuals, one can trace and highlight the following features of the linguistic representation of key concepts and feelings at an early stage:

Arthur $=$ cruelty:

Represented in dialogues in the form of the fear of others to do something that Arthur does want or say (I'll get in trouble; I am scared; I am afraid of ...) and it is explained by his rigorous and total control over each one, as disobedience is punished by being "undesired", which in fact means the end of the individual existence:

“... Oh, wow.” He gasped.

"What's the matter?"

"I told you Arthur's name. Now for sure I'll get in trouble for telling the secret."

"It's all right, I promised I wouldn't tell."

He cringed in his chair shaking. "I can't talk no more. I'm scared of him!...".

Tommy $=$ Desperation

The concept image is represented by describing Tommy's desperation and sometimes risky acts, as well as the reactions of others to him (Tommy, you goddamned sonofabitchin'; the famous one; the one who got outta them cuffs; the strait jacket cannot keep that one):

“... What Tommy did not tell her was that when he first heard that he might be transferred to Lima, he had bought a razor blade from a trusty. Right now it was taped to the sole of his left foot. He had learned long ago that when you are transferred from one institution to another, you always bring along a weapon ...".

Adalana $=$ uncontrollable thirst

In this case, the thirst became not only the core of Adalana's concept-image; the uncontrollable desire that gave impetus to all subsequent events and caused a number of negative consequences, therefore, the 
linguistic representation and reactions of individuals in dialogues with it are rather emotional and mostly negative (filthy slut; stupid lesbian; constantly blame myself; feel damn guilty; want out of boy's lives...):

“... I stole that time. I felt alcohol and pills. I did it. I ruined the boys' lives. But they just didn't understand ..."

"Understand what?" Turner asked.

"What the need for love is. To be held by someone. Just to feel warm and cared for. I don't know what made me do it."

Adalana paused and whispered, "Just for a few moments... I stole that time. Arthur didn't put me on the spot, so I wished Ragen off the spot and raped the girls...".

Ragen $=$ aggression

Ragen is a very strong and impulsive personality. Depending on the situation, hiss aggression can both protect and harm. For this reason, an important factor in the linguistic representation of the concept-image of this alter-him is, firstly, the phonetic peculiarity of his speech, namely the pronounced Slavic accent that, in American culture, at the subconscious level, is associated with rigorous Russians and totalitarian regimes of the communist countries; and secondly, straightforwardness and sincerity of his statements, Ragen does not pick up refined words, his sentences are rather simple, but expressive (lyrics, emotional exaggerations, extremes):

"... Turner discovered that Rorschach test showed Ragen the most potential for violent acting out...".

"... Ragen, I'm sorry for the trouble."

"Sorry!" Ragen snarled, pacing. "You filty slut. Vy for you go around raping vomans? Do you realize vat you put us all through? I hardly restis from killing you whore ...".

At the second stage, where positive changes were taking place in the state of Billy Milligan, the concept image changes as well. The shameless rascal treated with abomination and hatred, is transformed into a defenseless child, causing compassion and desire to help.

Within this conceptual phase, a sensual image of the defenseless infant, who, after being reborn from the rascal, who just begins to live and explore this world, becomes nucleus. Therefore, at the associative level, all of them seek to protect, help, support:

“... Dr. Marlene Kocan set up regular sessions, she even had tears from time to time when the personalities recalled their memories of abuse and torture, working them through and reliving the anguish that led to the major dissociation at the age of eight ...".

A striking change of the others attitude towards Billy is due not only to his willingness to treat and co-operate with the investigation, but also due to the shocking change of his ego-conditions: from perverts, criminals, sociopaths with characteristic rude and vulgar speech, to empathic "babies" in the body of Billy, with a stealthy tone and timid expression of feelings:

Danny $=$ fear

One of Billy's most afflicted and frightened personalities, who re-discovered himself from fear and shame at the time when the young man was pressed by interrogations and started medical treatment. In the dialogues the concept image is represented and distinguished from among others, especially emotional reactions (he is trembling; racing heart; he is scared; confused...):

"The first one Gary saw when he came to offer us help was Danny. He was scared and confused. He doesn't know much about what's going on ...".

Sean = protective mechanism ("I do not see anything / I do not hear anything")

The concept of dejection and deafness of mentally retarded Sean works as a protective mechanism in Billy's body during the time of particular despair, when nothing else but to close his eyes and close his ears remails, so as not to know the noise of the outside world and not to feel soul pain. A single sound representing this stunning concept-image is buzzing

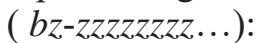

"Billy covered his ears with his hands. But he couldn't shut out his mothers screaming. Crying, he slowly slid down the door until he was sitting on the floor. He closed his eyes tight, and in Shawn's deafness everything went silent ...".

Robert (Bobby) $=$ uncertainty

unsure of himself and terse, others most often speak for him (he asks somebody from personalities to tell what he wants). He suffers from a complex of inferiority, and therefore appears at the moments of the oppressed state of Billy Milligan:

“... What a frustration.. he hated being called "Robert" by the others and would insist, "I'm Bobbyl" He had an inferiority complex, no ambition of his own, and he lived like a sponge, soaking up ideas and thoughts of others, passing them off as his own.".

The second concept phase is also connected to the most core personality, Billy Milligan, since he is like a baby in his own body: he almost did not live in the real world, but slept all the time; knows nothing and does not understand anything; the only thing a boy can do is to apologize for own actions and then try to commit a suicide:

"... In analyzing the psychodynamics of the case, Harding pointed out that Milligans natural fathers suicide increased his chances to do the same, because as a boy he deprived of fathers involvement and attention, and left him with "a feeling of irrational power and overwhelming guilt leading to anxiety, conflict and increased fantasy formulation ...".

In the third stage, when during productive group therapy communicative Allen, devout Samuel and experienced Teacher appeared themselves, there comes 
an expected improvement - it is already possible to follow the positive dynamics and fundamental changes in the behaviour of the boy:

“... Billy talked often with the young female patients. The nurses and mental health technicians knew that the young women were playing up to him, competing with each other for his attention. Nurse Pat Perry noticed that Mary, a former anthropology student, came out of her depression when Billy was around and talked to her. Billy admired Marys intelligence, often asking her advice, as she asked his. He missed her when she was discharged in January, but she promised to come back to visit him ...".

Samuel = devotion, charity

it is the first time that an atheist Billy turns to the devout alter-ego of Samuel (I swear to God; oh God; as God told us...). In addition, he decided to help the children and opened a bank account in the name of the charity fund and made a down payment:

“... He opened a bank account in the name of the Foundation Against Child Abuse and deposited a thousand dollars. He then had a bumper sticker printed, black letters on a yellow background: HUG YOUR CHILD TODAY “it's painless" PLEASE HELP STOP CHILD ABUSE! BILLY ... ”.

Allen $=$ communicability

Allen, unlike the others, if he has the right desire, easily finds an approach to anyone and can start a conversation on any subject, because in the concept of this personality there are laid down both the ability to exact sciences and art:

“... Those paintings are fascinating, ” Allen said, quickly glancing at the wall. "I prefer oils to acrylics, but whoever did those has a good eye for detail."

He saw Steinberg's expression change to one of interest.

\section{"You paint?"}

"All my life. Medicine is the career I've chosen... but maybe someday you'll let me paint your portrait. You've got a strong face....".

It was also found that bad individuals get "unwanted" and they are never allowed to the "stage", which gave a chance to suppress the bad in the sub-consciousness of Billy in general. Other individuals were not even allowed to be mentioned; only Allen for the greater effectiveness of group therapy tells the psychologist about "all those gentiles that we already buried here (pointing to his own the temple)."

And those of the "desirable" who performed bad deeds, such as Ragen, also began to change for the better and even saved a life of one of the patients:

“... Suddenly one of the female patients rushing toward the stairway railing outside the ward door a steep three-floor drop down the center staircase. Ragen took the spot, dashing down the corridor and up the steps, slamming open the door and running out into the hallway. Katherine Gillott, the mental health technician, reached the corridor in time to see him grab the girl, who had already gone over the railing. He held on and pulled her up ...".

In addition, so-called "common sense" of Billy Milligan - Teacher - contacts the doctors. He is of the same age, of the same sex and appearance as Billy; he remembers all the events, he is the one who would have been able to become the boy if he had not lost his own self. So there was a real opportunity to gradually combine all the sensible and good that is in Billy and "scramble together". That is why, at the third stage, agglomeration is the general purpose and the core of the concept of each of the "desired" individuals of Billy Milligan, that is, the gradual merging of his ego-states into a single complete personality.

This complex process took place due to the unification of all "desirable" personalities around Billy and Master in the conceptual sphere of "common consciousness" so that other voices eventually became silent, and Billy's voice became, if not the only, at least decisive:

“... Those voices like on replay ... ”

"Are you the only one who gets instant replay?"

Billy nodded.

"Because I'm the host, the core, I'm the one developing the co-consciousness."

"How do you feel about it?"

"It means I'm getting well, but it's scary ...".

4. Conclusions. Summing up the results of the conceptual analysis, and based on the on-phase changes in Billy Milligan's personality, one can distinguish the following set of concepts at each stage:

I concept phase: aggression; cruelty; hatred; perversion; moral decay; confusion; thirst for revenge; propensity to blackmail, crimes and suicide; unbalance; social affiliation;

II conceptual phase: uncertainty; conscientiousness; infantilism; feelings of guilt, loneliness and fear; helplessness; empathy;

III conceptual phase: decency; responsibility; communication; mercy; piety; industry.

Consequently, a comprehensive conceptual analysis proved that by exploring the connections of the cognitive mechanisms of the conscious and the unconscious, moving from the thought in the head of each of the individuals to the word that this or that ego-state of Billy as a separate living person could express his or her own emotions and experiences, one can fully, consistently and thoroughly reveal the concept of the linguistic representation of the multiple personality complex image in the artistic discourse.

In the artistic discourse to adequately reflect the situation associated with the super-complex psychological state of the novel protagonist, given the phenomenon of splitting his personality, the mere description of the disease from the diagnosis of doctors or medical aid was not enough. Therefore, for the full disclosure of the conceptual im- 
age of each of the 23 individuals in the body of Billy Milligan, the author used a number of linguistic style techniques and conceptual priorities, which subsequently formed a holistic psychological portrait of the multiple personality of the novel protagonist. Daniel Keyes paid particular attention to modeling the concept of each individual. Thus, the author revealed the links between the cognitive mechanisms of the conscious and the unconscious, moving from the thought in the head of each of the individuals to the word that this or that state of Billy as a separate living person, could react to different situations, expressing at the same time his own impressions, observation and experiences. Due to the methodology described one can easily investigate the psychological features of real personalities through their speech and linguistic peculiarities they adopt.

\section{BIBLIOGRAPHY}

Алефиренко Н.Ф. Лингвокультурология / Н.Ф. Алифиренко. - М.: Флинта, Наука, 2010. - 224 с.

Бєлєхова Л.І. Когнитивные операции обработки художественного текста / Л.І. Бєлєхова // Нова філологія : зб. наук. праць / редактор В. М. Манакін. - Запоріжжя : ЗНУ, 2012. - С. 30-38.

Бєлєхова Л.І. Когнитивные подходы в теории образности /Л.И. Белехова // Функциональная лингвистика: сб. науч. работ / науч. ред. А.Н. Рудяков. - Научный журнал, № 3 Симферополь: Изд-во Крымский республиканский институт последипломного педагогического образования, 2012. - С. 52-55.

Воронова М. Ю. Публіцистичний портрет: методологічні засади і сучасна модель / М. Ю. Воронова // Наукові записки Інституту журналістики : науковий збірник / за ред. В. В. Різуна ; КНУ імені Тараса Шевченка. - К., 2010. - Т. 41. - С. 42-46.

Гончарова Е.А. Пути лингвистического выражения категорий автор-персонаж. - Томск: Изд-во Томского ун-та, $1984 .-149$ с.

Красных В. В. Прецедентные высказывания и их функционирование в тексте / В. В. Красных // Лингвокогнитивные проблемы межкультурной коммуникации. - М.: Филология, 1997. - С. 100-115.

Кусько Е. Я. Проблемы языка современной художественной литературы : Несобственно-прямая речь в литературе ГДР /

Е. Я. Кусько. - Львів : Вища школа, 1980. - 207 с.

Стернин И.А. Методика исследования структуры концепта // Методологические проблемы когнитивной лингвистики: Научное издание / Под редакцией И.А. Стернина. - Воронеж, 2001. - С. 58-65.

Barnden J.A., Glasbey S.R., Lee M.G., Wallington A.M. Varieties and directions of inter-domain influence in metaphor // Metaphor and Symbol, 2004. - Vol. 19. - No 1. - P. 38-56.

Brodsky M. Learning Cultures in the Age of Globalization (precedent phenomena in intercultural communication and translation) /

M. Brodsky // Russia and China in the Modern Global World. - Changchun: Changchun Univ. Press, 2007. - P. 257-264.

Fairclough N. Language and Power / N. Fairclough. - L.: Longman Univ. Press, 1989. - 259 p.

Gannon M.B. Blood, Bedlam, Bullets, and Badguys: A Reader's Guide to Adventure / Suspense Fiction (Genre Reflecting Advisory

Series). Chicago: Libraries Unlimited, 2003. - $211 \mathrm{p}$.

Gentner, D., Wolff, P. Metaphor and Knowledge Change Text. / D. Gentner, P. Wolff // Cognitive Dynamics: Conceptual Change in Humans and Machines. - Mahwah, NJ : Lawrence Erlbaum Associates, 2000. — P. 295-342.

Keyes D. The Minds of Billy Milligan: A Novel / Daniel Keyes. - New York: Bantam Books, 2013. - 440 p.

Kövecses Z. Metaphor in culture: universality and variation. N.Y., 2005. - P. 314.

Munday J. Introducing Translation Studies / J. Munday. - L., N.Y.: Routledge, 2008. - 366 p.

Nayer, V.L. Stylistics and Pragmatics Text. / V.L Nayer. - M.: MSLU, 2002. 52 p.

Risager K. Language and Culture: Global Flows and Local Complexity / Karen Risager. - Multilingual Matters, Clevedon, $2006,-212$ pp.

Robinson D. Becoming a Translator. An Introduction to the Theory and Practice of Translation / D. Robinson. - N.Y.: Routledge, 2002. -346 p.

Snell-Hornby M. The Turns of Translation Studies / M. Snell-Hornby. - Amsterdam: Mouton de Grutier, 2006. - 295 p.

Van Dijk T.A. Discourse as Interaction in Society / T. A. van Dijk // Discourse as Social Interaction. Discourse Studies: A Multidisciplinary Introduction; ed. by T. A. van Dijk. - London: Thousand Oaks, 1997. - Vol. 2. - P. 1-37.

\section{REFERENCES}

Alefyrenko, N.F. (2010). Linhvokulturolohyia [Лингвокультурология]. Moscow: Flinta, Nauka.

Barnden, J.A., Glasbe, S.R., Lee M.G., Wallington, A.M. (2004). Varieties and directions of inter-domain influence in metaphor. NY. P. $38-56$.

Bieliekhova, L.I. (2012). Kohnytyvnye operatsyy obrabotky khudozhestvennoho teksta [Когнитивные операции обработки художественного текста]. Zaporizhzhia: ZNU. Pp. 30-38.

Bieliekhova, L.I. (2012). Kohnytyvnыe podkhodы v teoryy obraznosty [Когнитивные подходы в теории образности]. Symferopol: Krymskyi respublykanskyi ynstytut posledyplomnoho pedahohycheskoho obrazovanyia. pp. 52-55.

Brodsky, M. (2007) Learning Cultures in the Age of Globalization (precedent phenomena in intercultural communication and translation). Changchun: Changchun Univ. Press.

Fairclough, N. (1989). Language and Power. L.: Longman Univ. Press.

Gannon, M.B. (2003). Blood, Bedlam, Bullets, and Badguys: A Reader's Guide to Adventure. Chicago: Libraries Unlimited.

Gentner, D., Wolff, P. Metaphor and Knowledge Change Text. Mahwah, NJ : Lawrence Erlbaum Associates.

Honcharova, E.A. (1984). Puty lynhvystycheskoho vyrazhenyia katehoryi avtor-personazh [Пути лингвистического выражения категорий автор-персонаж]. Tomsk. 
Keyes, D. (2013). The Minds of Billy Milligan. New York: Bantam Books.

Kövecses, Z. (2005). Metaphor in culture: universality and variation. N.Y.

Krasnykh, V. V. (1997). Pretsedentnye vyskazyvanyia y ykh funktsyonyrovanye v tekste [Прецедентные высказывания и их функционирование в тексте]. М.: Fylolohyia, Pp. 100-115.

Kusko, E. Ya. (1980). Problemy yazyka sovremennoi khudozhestvennoi lyteratury: Nesobstvenno-priamaia rech v lyterature HDR [Проблемы языка современной художественной литературы : Несобственно-прямая речь в литературе ГДР]. Lviv: Vyshcha shkola.

Munday, J. (2008). Introducing Translation Studies. N.Y.: Routledge.

Nayer, V.L. (2002). Stylistics and Pragmatics Text. M.: MSLU.

Risager, K. (2006). Language and Culture: Global Flows and Local Complexity. Multilingual Matters, Clevedon.

Robinson, D. (2002). Becoming a Translator. An Introduction to the Theory and Practice of Translation. N.Y.: Routledge.

Snell-Hornby, M. (2006). The Turns of Translation Studies. Amsterdam: Mouton de Grutier.

Sternyn, Y.A. (2001). Metodyka yssledovanyia struktury kontsepta [Методика исследования структуры концепта]. Voronezh.

Van Dijk T.A. (1997). Discourse as Interaction in Society. London: Thousand Oaks,- Vol. 2. - P. 1-37.

Voronova, M.Yu. (2010). Publitsystychnyi portret: metodolohichni zasady i suchasna model [Публіцистичний портрет: методологічні засади і сучасна модель] K.: KNU imeni Tarasa Shevchenka. Pp. 42-46.

\begin{abstract}
Анотація
У статті наведено результати концептуального дослідження поняття портрету множинної особистості та процесу формування концептуальної сфери на ії підсвідомому, психічному та психологічному рівнях на матеріалі англійської мови. Психологічний портрет - це складова частина художнього образу, оскільки художній образ є сукупністю декількох портретів персонажа. 3 огляду на особливості концептуалізації та мовної репрезентації психологічного портрета в англомовному художньому дискурсі, важливого значення також набуває питання залежності концепту від мовної вербалізації. Лінгвістичні та концептуальні особливості представлення множинної особистості у англомовній художній літературі були ретельно розглянуті в романі «Таємнича історія Біллі Міллігана» Даніела Кіза. Дослідження показали, що психологічний портрет множинної особистості Біллі Міллігана можна досліджувати лише як складний образ, оскільки в нього входить 23 альтер-его з розщепленою концептуальною сферою. Для повноцінного розкриття концепт-образу кожної особистості у тілі Біллі Міллігана, автор використав ряд лінгвостилістичних прийомів та концептуальних пріоритетів, що згодом й сформували цілісний психологічний портрет множинної особистості головного героя роману, репрезентованої за допомогою концептів, вербалізованих у англомовному тексті за допомогою лінгвостилістичних засобів. Даніел Кіз приділяє особливу увагу моделюванню концептосфери кожної із зазначених особистостей. Таким чином, автор розкривав зв'язки пізнавальних механізмів свідомого та позасвідомого, рухаючись від думки в голові кожної із особистостей до слова, яким той чи інший его-стан Біллі, як окрема жива людина, міг би реагувати на різні ситуації, висловлюючи при цьому власні враження, спостереження та переживання. Залежно від їх функцій, стадії розвитку та рівня самоочищення основної особистості кожна нова концепція була представлена за допомогою різних мовних та стилістичних засобів англійської мови. Під час проведення дослідження було визначено, що процес вербалізації концептуальної сфери є вкрай складним і основується на аналізі психологічного та підсвідомого рівнів.
\end{abstract}

\title{
Ключові слова
}

Художня література, багатоваріантність, психологічний портрет, концепт, концептуальна сфера, вербалізація, лінгвістичні та стилістичні засоби. 